\title{
PENGARUH IKLIM KEAGAMAAN LEMBAGA PAUD TERHADAP \\ PERKEMBANGAN NILAI AGAMA DAN MORAL ANAK USIA DINI SE-KOTA YOGYAKARTA
}

\author{
Amir Syamsudin \\ Pendidikan Guru PAUD, Universitas Negeri Yogyakarta \\ e-mail: amirsyamsudin@uny.ac.id
}

\begin{abstract}
Abstrak
Tujuan penelitian ini untuk membuktikan pengaruh iklim keagamaan di lembaga PAUD terhadap perkembangan moral anak usia 5-6 tahun se-kota Yogyakarta. Populasi penelitian sebanyak 222 taman kanak-kanak se-Kota Yogyakarta. Sample penelitian berjumlah 143 taman kanak-kanak, dengan tingkat kesalahan penarikan sample sebesar 5\%. Cara menarik sample menggunakan teknik clustered proportional random sampling. Satuan analisis penelitian meliputi iklim keagamaan di sekolah, pengalaman kerja guru PAUD, perkembangan NAM anak usia 5-6 tahun, dan persepsi kepala TK tentang kinerja guru. Responden penelitian terdiri atas kepala taman kanak-kanak, anak usia 5-6 tahun, dan guru PAUD se-kota Yogyakarta. Temuan penelitian ialah ada hubungan yang signifikan antara iklilm keagamaan di lembaga PAUD dengan perkembangan nilai-nilai agama dan moral anak usia 5-6 tahun seKota Yogyakarta. Hubungan tersebut bersifat signifikan karena skor korelasi Pearson (0.772) mendekati skor 1 (korelasi sempurna) dan melampaui skor minimal korelasi $\geq 0.5$. Hal ini mengonfirmasi sekaligus memperkuat teori bahwa iklim keagamaan berpengaruh terhadap perkembangan nilai-nilai agama dan moral anak usia dini.
\end{abstract}

Kata Kunci: nilai-nilai agama dan moral, iklim keagamaan, pendidikan anak

\section{THE RELATIONSHIP OF RELIGIOUS ACTIVITY WITH THE DEVELOPMENT OF RELIGIOUS AND MORAL VALUES OF EARLY CHILDHOOD IN YOGYAKARTA}

\begin{abstract}
The purpose of this study is to prove the relationship of religious activity with the development of religious and moral values of children aged 5-6 years in Yogyakarta. The research population is 222 kindergartens in Yogyakarta. The sample of this study was 143 kindergartens, with 5\% sampling error rate. How to draw sample using clustered proportional random sampling technique. The unit of research analysis includes religious activities in kindergarten, teacher work experience, religious and moral development of children aged 5-6 years, and headmaster perceptions of teachers' performance. The study respondents consisted of head of kindergarten, children aged 5-6 years, and kindergarten teachers in Yogyakarta. The research findings are a significant relationship between religious activities in kindergarten and the development of religious and moral values of children aged 5-6 years in Yogyakarta. The relationship is significant because the Pearson correlation score (0.772) approaches score 1 (perfect correlation) and exceeds the minimum correlation score $\geq 0.5$. This confirms and reinforces the theory that religious activity influences the development of religious and moral values of early childhood.
\end{abstract}

Keywords: religious and moral values, religious activity, early childhood education.

\begin{tabular}{cl}
\hline \hline PENDAHULUAN & diselenggarakan oleh keluarga, sekolah, \\
Tujuan pendidikan ialah & dan masyarakat. Ayah dan ibu di rumah \\
memanusiakan manusia. Pendidikan dapat & sebagai guru keluarga mempunyai
\end{tabular}


tanggung jawab yang sama dengan guru di sekolah atau pemuka agama di masyarakat untuk mewujudkan cita-cita pendidikan tersebut.

Penelitian tentang proses pendidikan anak telah dilakukan peneliti terdahulu seperti oleh Harris \& Koenig (2006). Simpulan Harris \& Koenig bahwa proses pemahaman anak terhadap konsep "Tuhan" dan "kehidupan setelah mati" memiliki kemiripan dengan proses pemahaman anak terhadap konsep "ilmu pengetahuan". Konsep-konsep tersebut tidak dapat diobservasi dan anak hanya mempercayai "pendapat" orang dewasa tentang keduanya (Harris \& Koenig, 2006:505).

Penelitian Mahoney dkk. (2001) tentang hubungan agama dengan fungsi keluarga dalam kehidupan anak. Ada hubungan yang lemah antara ketaatan ayah dan ibu terhadap agama dengan berkurangnya potensi perceraian keduanya, dan memaksimalkan fungsi keluarga dalam kehidupan anak. Ada hubungan yang moderat antara keluarga kristen konservatif dengan kebolehan pemberian hukuman fisik kepada anak. Ada hubungan yang kuat antara sifat religious orang tua dengan pengasuhan anak dan penyesuaian diri anak terhadap lingkungan.

Mengajarkan kebaikan kepada anak sejak usia dini merupakan tanggung jawab dari orang tua. Ada tiga jenis kebaikan dasar yang perlu dikenalkan orang tua kepada anak-anaknya, yaitu manfaat mengenal agama dan Tuhan, manfaat tepat waktu dalam mengikuti kegiatan, dan manfaat memiliki hobi (Kompas.com, 15/01/2017).

Pengenalan anak tentang Tuhan untuk menumbuhkan kesadaran bahwa ada kekuatan yang melampau kekuatan tangan, mata, telinga, hidung, dan lidah anak dalam memahami lingkungan. Kekuatan ini bersifat ramah, bersahabat dengan anakanak, dan pemurah. Tuhan menyediakan udara, sinar matahari, tanah yang subur, air yang jernih, api yang menerangi dengan gratis.
Pengenalan manfaat tepat waktu bagi anak usia dini bertujuan menumbuhkan kesadaran menghargai sesuatu yang tidak dapat dibeli atau dijual, yaitu waktu. Anak dibiasakan untuk tepat waktu dalam makan, tidur, cuci tangan, bermain, atau hiburan.

Pengenalan manfaat memiliki hobi kepada anak usia dini bertujuan menggali minat, kesukaan, dan bakat yang dapat dikembangkan oleh anak. Apabila anak mulai menyadari minat, kesukaan, dan bakatnya, maka anak akan menggunakan waktu luang untuk mengasah hobinya tersebut.

Ketiga kebaikan dasar tersebut sepantasnya dibiasakan di lingkungan lembaga PAUD. Namun masih sedikit yang meneliti pengaruh agama dan proses pembelajarannya terhadap perkembangan anak di lembaga PAUD.

"Agama memberi pengaruh positif pada kehidupan anak usia dini, tetapi pengaruh agama terhadap perkembangan anak usia dini sangat jarang diteliti" (Bartkowski, dkk., 2008: 19-20). Penelitian yang sedang banyak dilakukan adalah tentang nilai-nilai agama dalam keluarga, praktik pengasuhan anak, keterlibatan ayah dalam pengasuhan anak, dan kasih sayang orang tua kepada anak. Disamping itu juga telah terbukti bahwa ikatan anak dengan orang tua dapat ditingkatkan melalui agama. Penelitian tentang hubungan agama dan anak-anak di Amerika misalnya, menunjukkan bahwa keyakinan agama menduduki posisi penting dalam kesadaran anak-anak usia 10-an tahun dan menghindarkan mereka dari perilaku buruk.

Anak mempelajari prinsip-prinsip moral, pengetahuan keagamaan, kewajiban adat istiadat, dan praktik ibadah dari lingkungan keluarga dan sekolah (Kitching \& Shanneik, 2015: 11). Karakter/budi pekerti/akhlak dapat dimaknai batas-batas moralitas. Budi pekerti dapat dipertajam dengan bertindak atas dasar nilai yang benar selama proses interaksi sosial di rumah dan sekolah (Leunissen, 2012: 508). Hubungan antara pendidikan dan agama 
mengasumsikan bahwa keterlibatan anak dalam aktivitas keagamaan tidak semata dipengaruhi keyakinan agama, tetapi juga karena agama mempengaruhi pembentukan kebiasaan positif anak (Fan, 2006: 2). Ada bukti kuat yang menunjukkan bahwa agama memberi pengaruh positif pada perkembangan anak dan kematangan kepribadian mereka di masa yang akan datang. Hasil penelitian sosiolog menemukan bukti-bukti bahwa agama dapat mencegah anak-anak dari tindak kekerasan dan bahkan Narkoba. Agamaagama di dunia sangat menganjurkan kepada para pengikutnya untuk bekerja keras, jujur, bersungguh-sungguh, dan bertanggung jawab. Bukti-bukti tersebut menguatkan teori yang menyatakan bahwa agama mempengaruhi secara positif terhadap perkembangan mental anak.

Setiap anak memiliki dorongan dari dalam dirinya sendiri untuk beragama (Wessells, Michael and Alison Strang, 2006: 205). Dorongan ini mengarahkan anak untuk berinteraksi dengan dunia dan memaknai interaksi tersebut. Anak dapat merasakan perbedaan antara perbuatan adil dan tidak adil yang dilakukan orang lain terhadap dirinya. Sejak anak lahir, lingkungan keluarga telah mengajarkan praktik ritual keagamaan dengan maksud agar anak menyerap nilai-nilai agama, pencerahan keagamaan, dan memahami sumber keselamatan keluarganya secara turun temurun. Menjadi anggota keluarga bagi anak bermakna bahwa nilai-nilai agama, keyakinan, dan adat istiadat keluarga juga harus menjadi bagian dari dirinya.

Tujuan pendidikan agama dalam keluarga dan sekolah ialah untuk pembiasaan perilaku prososial, mengenalkan sistem keyakinan keagamaan, mempromosikan nilai-nilai kewajaran dalam bertindak, berjiwa kesatria, jujur, menghormati semua makhluk hidup, dan peduli pada lingkungan (Flourish ItuluaAbumere, 2013: 71). Pendidikan agama telah mendorong rasa ingin tahu anak tentang berbagai macam keyakinan agama, nilai, dan budaya lain, sementara pada saat yang sama anak juga memperdalam pemahaman terhadap keyakinan agamanya sendiri. Pendidikan agama juga membantu anak untuk mematangkan diri secara pribadi maupun sosial untuk siap menjalani kehidupan ini dengan sehat dan damai.

Daya kenyal terhadap krisis kehidupan yang dialami anak dapat diasah melalui aktivitas keagamaan. Daya kenyal (resilience) merupakan kemampuan untuk hidup dalam situasi yang sulit, kemampuan mengatasi setiap kesulitan hidup, kemampuan untuk bangkit dan cepat melupakan kenyataan pahit, dan kemampuan memikul beban mental (Gunnestad \& Thwala, 2011:169). Hasil temuan Gunnestad dan Thwala di Afrika Tenggara menunjukkan bahwa agama berperan penting dalam budaya dan pandangan dunia bangsa Afrika, termasuk anak-anak dalam membantu mereka keluar dari krisis kehidupan. Agama berhasil memahamkan anak-anak untuk memahami situasi krisis dan secara kesatria menghadapinya.

\section{METODE}

Metode penelitian yang digunakan adalah kuantitatif. Jenis data yang dikumpulkan adalah rasio, baik untuk data perkembangan moral anak maupun data aktivitas keagamaan di lingkungan sekolah. Responden dipilih secara acak dari populasi anak usia dini, guru PAUD, kepala lembaga PAUD se-Kota Yogyakarta. Jumlah TK seKota Yogyakarta ialah 222 TK, baik negeri maupun swasta per Agustus 2017 seperti pada Tabel 1, dan tersebar di 14 wilayah kecamatan se-Kota Yogyakarta. Masingmasing wilayah kecamatan memperoleh hak yang sama untuk mewakili TK sesuai dengan jumlah TK yang ada di setiap kecamatan. Ringkasnya, wilayah kecamatan yang memiliki TK sedikit, maka wakil per wilayah jumlahnya juga sedikit, sebaliknya wilayah kecamatan yang memiliki TK banyak akan diwakili oleh jumlah TK yang lebih banyak pula. 
Tabel 1.

Sebaran Lembaga PAUD (TK)

per Kecamatan di Kota Yogyakarta

\begin{tabular}{|c|l|c|c|}
\hline No & Kecamatan & Populasi & ES 5\% \\
\hline 1 & Danurejan & 10 & 6 \\
\hline 2 & Gedongtengen & 11 & 7 \\
\hline 3 & Gondokusuman & 25 & 16 \\
\hline 4 & Gondomanan & 6 & 4 \\
\hline 5 & Jetis & 17 & 11 \\
\hline 6 & Kotagede & 18 & 12 \\
\hline 7 & Kraton & 12 & 8 \\
\hline 8 & Mantrijeron & 18 & 12 \\
\hline 9 & Mergangsan & 18 & 12 \\
\hline 10 & Ngampilan & 8 & 5 \\
\hline 11 & Pakualaman & 9 & 5 \\
\hline 12 & Tegalrejo & 14 & 9 \\
\hline 13 & Umbulharjo & 38 & 24 \\
\hline 14 & Wirobrajan & 18 & 12 \\
\hline Jumlah Populasi/Sample & 222 & 143 \\
\hline
\end{tabular}

Sumber: IGTKI Yogyakarta 2017.

Teknik pemilihan sample yang digunakan dalam penelitian ini adalah clustered proportional random samling. Tujuan dari cluster ialah mengelompokkan lembaga PAUD berdasarkan wilayah kecamatan. Tujuan dari penjatahan setiap wilayah kecamatan ialah unsur keterwakilan dari masing-masing wilayah. Tujuan dari acak ialah menemukan anak usia 5-6 tahun, guru PAUD, dan kepala lembaga PAUD dari keseluruhan populasi anak usia 5-6 tahun, guru PAUD, dan kepala lembaga PAUD se-Kota Yogyakarta secara adil dan memiliki hak yang sama untuk terpilih menjadi responden penelitian ini. Teknik analisis data yang digunakan adalah korelasi Pearson.

Kisi-kisi instrumen penelitian meliputi variabel aktivitas keagamaan di sekolah dan variabel perkembangan nilai agama dan moral anak usia dini. Aktivitas keagamaan di sekolah terdiri dari kegiatan keagamaan seperti menghafal do'a-do'a pendek, melaksanakan ibadah, berperilaku baik sesuai ajaran agama, mengenal hari besar agama, tempat ibadah, dan tokohtokoh keagamaan, berkata sopan kepada setiap orang, peduli kepada orang lain, dan mau menolong orang lain. Sedangkan perkembangan nilai agama dan moral anak usia dini meliputi pembiasaan berdo'a, kebersihan diri, kesantunan interaksi selama proses pembelajaran, dan pengetahuan-keterampilan beribadah yang sesuai dengan perkembangan anak usia dini.

Ada tiga jenis lembar instrumen penelitian. Lembar pertama dan kedua berisi pernyataan tentang iklim keagamaan di lingkungan sekolah. Lembar pertama diisi oleh kepala sekolah dengan cara mengamati guru selama proses interaksi pembelajaran dengan anak dan lembar kedua diisi oleh guru PAUD pengampu kelompok anak usia 5-6 tahun sebagai refleksi diri atas proses pembelajaran yang dilakukannnya. Lembar ketiga berisi tentang ciri perkembangan nilai agama dan moral anak usia 5-6 tahun. Lembar ini diisi oleh guru PAUD yang mengampu di kelompok anak usia 5-6 tahun. Jumlah anak yang diobservasi hanya satu orang dan dipilih secara acak oleh guru PAUD masing-masing lembaga. Ketiga lembar instrumen tersebut menggunakan skala 1 7 untuk tanggapan atas masing-masing butir pernyataan.

Jumlah lembaga PAUD yang menjadi responden penelitian ini sebanyak 143 lembaga dan masing-masing lembaga memperoleh 1 set instrumen penelitian. Ada 134 set instrumen penelitian yang berhasil dikumpulkan dan ada 9 set intrumen penelitian yang tidak diisi oleh responden atau diisi sebagian sehingga tidak disertakan dalam proses tabulasi data.

Hasil tabulasi data berjumlah 134 set data yang lengkap, namun ditemukan 8 set data outlier yang melampaui kriteria $z$ score $( \pm 2)$ sehingga tidak diikutkan dalam analisis selanjutnya. Dengan demikian jumlah data yang diolah sebanyak 126 set data yang terdiri dari variable pengalaman kerja guru, perkembangan NAM anak usia dini, persepsi guru tentang iklim keagamaan di sekolah, dan persepsi kepala sekolah tentang kinerja guru dalam membangun iklim keagamaan di sekolah. 
Kedelapan responden tersebut bernomor 11, 39, 63, 70, 72, 77, 82, dan 128 .

\section{HASIL DAN PEMBAHASAN \\ Hasil}

Hasil penelitian yang diuraikan pada bagian ini meliputi deskripsi statistik data penelitian pengalaman kerja guru, penumbuhan iklim keagamaan di lingkungan sekolah, kinerja guru PAUD, dan ciri perkembangan nilai-nilai agama dan moral anak usia 5-6 tahun. Uraian rinci meliputi distribusi frekuensi, persyaratan generalisasi sample ke populasi, dan analisis korelasi antara kondisi keagamaan dengan perilaku moral anak usia 5-6 tahun. Responden yang dianalisis sebanyak 126 pasangan subjek, yaitu kepala sekolah, guru PAUD, dan anak usia dini.

Tabel 2.Distribusi Frekuensi Data Iklim Keagamaan, Pengalaman Kerja, Perkembangan NAM, dan Kinerja Guru PAUD

\begin{tabular}{|c|c|c|c|c|c|}
\hline & & & tatistics & & \\
\hline & & IK & PK & NAM & $\mathrm{KG}$ \\
\hline $\mathrm{N}$ & $\mathrm{V}$ & 126 & 126 & 126 & 126 \\
\hline$N$ & $\mathrm{M}$ & 0 & 0 & 0 & 0 \\
\hline $\mathrm{Mc}$ & & 84.9603 & 17.357 & 83.0898 & 84.6542 \\
\hline Stc & & .96089 & .81099 & 1.00551 & .92160 \\
\hline & & 86.0714 & 17.000 & 84.1270 & 85.7143 \\
\hline Stc & & 10.78597 & 9.10337 & 11.28687 & 10.34496 \\
\hline $\mathrm{Va}$ & & 116.337 & 82.871 & 127.394 & 107.018 \\
\hline & & -.379 & .295 & -.380 & -.354 \\
\hline Stc & & .216 & .216 & .216 & .216 \\
\hline $\mathrm{Ku}$ & & -.826 & -.890 & -.804 & -.750 \\
\hline & & .428 & .428 & .428 & .428 \\
\hline $\mathrm{Ra}$ & & 40.71 & 34.00 & 42.86 & 39.29 \\
\hline & & 59.29 & 1.00 & 57.14 & 60.71 \\
\hline & & 100.00 & 35.00 & 100.00 & 100.00 \\
\hline & 10 & 69.2857 & 5.0000 & 67.5661 & 70.0000 \\
\hline & 25 & 77.1429 & 11.0000 & 75.1323 & 78.3929 \\
\hline$\%$ & 50 & 86.0714 & 17.0000 & 84.1270 & 85.7143 \\
\hline & 75 & 93.7500 & 24.7500 & 93.1217 & 94.2857 \\
\hline & 90 & 99.2857 & 31.0000 & 97.3545 & 98.0714 \\
\hline
\end{tabular}

Sumber: Data Penelitian Mandiri 2017

Variabel iklim keagamaan di sekolah memiliki rerata skor sebesar 84.96 dengan standard error of mean sebesar 0.96. Angka standard deviation sebesar 10.78 menunjukkan variasi data yang sedikit karena kurang dari 20\% $(10.78 / 84.96=12.69 \%)$ dan skor varians sebesar 116.33. Rentang rerata skor iklim keagamaan terletak diantara angka $84.96 \pm$ (3 x 0.96=2.88), yaitu 82.02 sampai dengan 87.84. Skor median menunjukkan bahwa $50 \%$ iklim keagamaan di sekolah telah mencapai skor 86.07. Rentang skor iklim keagamaan di sekolah terletak diantara angka $84.96 \pm(3 \times 10.78=32.34)$, yaitu 52.26 sampai dengan 117.3.

Ukuran skewness sebesar -0.379 dan standard error skewness sebesar 0.216. Skor rasio skewness sebesar -0.379/0.216 sama dengan -1.758. Ukuran kurtosis sebesar -0.826 dan standard error kurtosis sebesar 0.428. Skor rasio kurtosis sebesar $0.826 / 0.428$ sama dengan -1.928. Kedua angka ini berada diantara \pm 2 dalam distribusi normal sehingga data iklim keagamaan dapat dipastikan sebaran datanya berdistribusi normal dan memenuhi syarat untuk generalisasi dari sample ke populasi. Skor range sebesar 40.71, skor maksimum 100, skor minimum 59.29, dan 90\% sekolah memiliki skor rerata iklim keagamaan sebesar 99.28.

Tabel 3. Distribusi Frekuensi Iklim Keagamaan di Lembaga PAUD se-Kota Yogyakarta

\begin{tabular}{|c|c|c|c|c|}
\hline No & Kelas Interval & $f$ & $\%$ & $\%$ cum. \\
\hline 1 & $\geq 97.50$ & 18 & 14.29 & 14.29 \\
\hline 2 & $91.50-97.49$ & 21 & 16.67 & 30.95 \\
\hline 3 & $85.50-91.49$ & 28 & 22.22 & 53.17 \\
\hline 4 & $79.50-85.49$ & 20 & 15.87 & 69.05 \\
\hline 5 & $73.50-79.49$ & 14 & 11.11 & 80.16 \\
\hline 6 & $67.50-73.49$ & 17 & 13.49 & 93.65 \\
\hline 7 & $61.50-67.49$ & 6 & 4.76 & 98.41 \\
\hline 8 & $\leq 61.49$ & 2 & 1.59 & 100 \\
\hline \multicolumn{2}{|r|}{ Jumlah } & 126 & 100 & \\
\hline
\end{tabular}

Sumber: Data Penelitian Mandiri 2017

Iklim keagamaan yang dibangun oleh guru di lembaga PAUD sudah mencapai $53.17 \%$ di atas rerata dan $46.83 \%$ di bawah rerata. Rerata skor iklim keagamaan di lembaga PAUD sebesar 84.96. Ada 18 lembaga PAUD yang memiliki skor iklim keagamaan lebih besar atau sama dengan 97.50, dan masih ada 2 lembaga PAUD yang memiliki skor iklim keagamaan lebih kecil dari 61.49.

Variabel pengalaman kerja guru PAUD memiliki rerata skor sebesar 17.35 dengan standard error of mean sebesar 0.81. Angka standard deviation sebesar 9.10 menunjukkan variasi data yang banyak karena lebih besar dari 20\% $(9.10 / 17.35=52.44 \%)$ dan skor varians 
sebesar 82.87. Rentang rerata skor pengalaman kerja guru PAUD terletak diantara angka $17.35 \pm(3 \times 0.81=2.43)$, yaitu 14.92 sampai dengan 19.78. Skor median menunjukkan bahwa 50\% pengalaman guru di sekolah telah mencapai skor 17 tahun ke atas. Rentang skor pengalaman kerja guru PAUD terletak diantara angka $17.35 \pm(3 \times 9.10=27.3)$, yaitu 9.95 sampai dengan 44.65.

Ukuran skewness sebesar 0.295 dan standard error skewness sebesar 0.216. Skor rasio skewness sebesar 0.295/0.216 sama dengan -1.369. Ukuran kurtosis sebesar -0.890 dan standard error kurtosis sebesar 0.428. Skor rasio kurtosis sebesar 0.890/0.428 sama dengan -2.078. Kedua angka ini berada diantara \pm 2 dalam distribusi normal sehingga data pengalaman kerja guru PAUD dapat dipastikan sebaran datanya berdistribusi normal dan memenuhi syarat untuk generalisasi dari sample ke populasi. Skor range sebesar 34 tahun, skor maksimum 35 tahun, skor minimum 1 tahun, dan 90\% pengalaman kerja guru memiliki skor sebesar 31 tahun.

Tabel 4. Distribusi Frekuensi Pengalaman Kerja Guru PAUD se-Kota Yogyakarta

\begin{tabular}{|c|c|c|c|c|}
\hline No & Kelas Interval & $f$ & $\%$ & \% cum. \\
\hline 1 & $\geq 32.50$ & 5 & 3.97 & 3.97 \\
\hline 2 & $27.50-32.49$ & 25 & 19.84 & 23.81 \\
\hline 3 & $22.50-27.49$ & 2 & 1.59 & 25.39 \\
\hline 4 & $17.50-22.49$ & 28 & 22.22 & 47.62 \\
\hline 5 & $12.50-17.49$ & 21 & 16.67 & 64.29 \\
\hline 6 & $7.50-12.49$ & 27 & 21.43 & 85.71 \\
\hline 7 & $2.50-7.49$ & 16 & 12.69 & 98.41 \\
\hline 8 & $\leq 2.49$ & 2 & 1.59 & 100 \\
\hline \multicolumn{2}{|r|}{ Jumlah } & 126 & 100 & \\
\hline
\end{tabular}

Sumber: Data Penelitian Mandiri 2017

Pengalaman bekerja para guru di lembaga PAUD sudah mencapai $47.62 \%$ di atas rerata dan $52.38 \%$ di bawah rerata. Rerata skor pengalaman kerja guru di lembaga PAUD sebesar 17.35 tahun. Ada 5 lembaga PAUD yang memiliki skor pengalaman bekerja guru lebih besar atau sama dengan 32.50 tahun, dan masih ada 2 lembaga PAUD yang memiliki skor pengalam kerja guru lebih kecil dari 2.49 tahun.

Variabel perkembangan NAM memiliki rerata skor sebesar 83.08 dengan standard error of mean sebesar 1.00 . Angka standard deviation sebesar 11.28 menunjukkan variasi data yang sedikit karena kurang dari 20\% $(10.78 / 84.96=13.58 \%)$ dan skor varians sebesar 127.39. Rentang rerata skor perkembangan NAM anak usia dini terletak diantara angka $83.08 \pm(3 \times 1=3)$, yaitu 80.08 sampai dengan 86.08 . Skor median menunjukkan bahwa 50\% perkemabangan NAM anak usia dini telah mencapai skor 86.07. Rentang skor iklim keagamaan di sekolah terletak diantara angka $83.08 \pm(3 \mathrm{x}$ $11.28=33.84)$, yaitu 49.24 sampai dengan 116.92 .

Ukuran skewness sebesar -0.380 dan standard error skewness sebesar 0.216. Skor rasio skewness sebesar -0.380/0.216 sama dengan -1.763. Ukuran kurtosis sebesar -0.804 dan standard error kurtosis sebesar 0.428. Skor rasio kurtosis sebesar $0.804 / 0.428$ sama dengan -1.878 . Kedua angka ini berada diantara \pm 2 dalam distribusi normal sehingga data perkembangan NAM anak usia dini dapat dipastikan sebaran datanya berdistribusi normal dan memenuhi syarat untuk generalisasi dari sample ke populasi. Skor range sebesar 42.86, skor maksimum 100, skor minimum 57.14, dan 90\% perkembangan NAMA anak usia dini memiliki skor rerata 97.35.

Perkembangan NAM anak usia dini sudah mencapai $48.41 \%$ di atas rerata dan $51.59 \%$ di bawah rerata. Rerata skor perkembangan NAM anak usia dini sebesar 84.65. Ada 14 lembaga PAUD yang memiliki skor perkembangan NAM anak usia dini lebih besar atau sama dengan 96.50, dan masih ada 3 lembaga PAUD yang memiliki skor perkembangan NAM anak usia dini lebih kecil dari 60.49.

Tabel 5. Distribusi Frekuensi Perkembangan Nilai Agama dan Moral Anak Usia 5-6 tahun se-Kota Yogyakarta

\begin{tabular}{|c|c|c|c|c|}
\hline No & Kelas Interval & $\boldsymbol{f}$ & $\boldsymbol{\%}$ & \% cum. \\
\hline 1 & $\geq 96.50$ & 14 & 11.11 & 11.11 \\
\hline
\end{tabular}




\begin{tabular}{|c|c|c|c|c|}
\hline 2 & $90.50-96.49$ & 25 & 19.84 & 30.95 \\
\hline 3 & $84.50-90.49$ & 22 & 17.46 & 48.41 \\
\hline 4 & $78.50-84.49$ & 24 & 19.05 & 67.46 \\
\hline 5 & $72.50-78.49$ & 12 & 9.52 & 76.98 \\
\hline 6 & $66.50-72.49$ & 20 & 15.87 & 92.86 \\
\hline 7 & $60.50-66.59$ & 6 & 4.76 & 97.62 \\
\hline 8 & $\leq 60.49$ & 3 & 2.38 & 100 \\
\hline \multicolumn{2}{|r|}{ Jumlah } & 126 & 100 & \\
\hline
\end{tabular}

Sumber: Data Penelitian Mandiri 2017

Variabel kinerja guru PAUD di sekolah memiliki rerata skor sebesar 84.65 dengan standard error of mean sebesar 0.92. Angka standard deviation sebesar 10.34 menunjukkan variasi data yang sedikit karena kurang dari 20\% $(10.34 / 84.65=12.22 \%)$ dan skor varians sebesar 107.08. Rentang rerata skor kinerja guru PAUD terletak diantara angka $84.65 \pm$ ( 3 x $0.92=2.76$ ), yaitu 81.89 sampai dengan 87.41. Skor median menunjukkan bahwa 50\% kinerja guru PAUD telah mencapai skor 85.71. Rentang skor kinerja guru PAUD terletak diantara angka $84.65 \pm(3 \mathrm{x}$ $10.34=31.02$ ), yaitu 53.63 sampai dengan 115.67

Ukuran skewness sebesar -0.354 dan standard error skewness sebesar 0.216. Skor rasio skewness sebesar -0.354/0.216 sama dengan -1.642. Ukuran kurtosis sebesar -0.750 dan standard error kurtosis sebesar 0.428. Skor rasio kurtosis sebesar $0.750 / 0.428$ sama dengan -1.750. Kedua angka ini berada diantara \pm 2 dalam distribusi normal sehingga data kinerja guru PAUD dapat dipastikan sebaran datanya berdistribusi normal dan memenuhi syarat untuk generalisasi dari sample ke populasi. Skor range sebesar 39.29, skor maksimum 100, skor minimum 60.71 , dan $90 \%$ kinerja guru PAUD memiliki skor rerata sebesar 98.07.

Tabel 6.Distribusi Frekuensi Data Persepsi Kepala Sekolah tentang Kinerja Guru Membangun Iklim Keagamaan PAUD

\begin{tabular}{|c|c|c|c|c|}
\hline No & Kelas Interval & $\boldsymbol{f}$ & \% & \% cum. \\
\hline 1 & $\geq 94.50$ & 29 & 23.01 & 23.01 \\
\hline 2 & $89.50-94.49$ & 17 & 13.49 & 36.50 \\
\hline 3 & $84.50-89.49$ & 18 & 14.29 & 50.79 \\
\hline
\end{tabular}

\begin{tabular}{|c|c|c|c|c|}
4 & $79.50-84.49$ & 26 & 20.63 & 71.42 \\
\hline 5 & $74.50-79.49$ & 11 & 8.73 & 80.15 \\
\hline 6 & $69.50-74.49$ & 14 & 11.11 & 91.26 \\
\hline 7 & $64.50-69.49$ & 6 & 4.77 & 96.03 \\
\hline 8 & $\leq 59.49$ & 5 & 3.97 & 100 \\
\hline & & 126 & 100 & \\
\hline
\end{tabular}

Sumber: Data Penelitian Mandiri 2017

Kinerja guru dalam menumbuhkan iklim keagamaan sudah mencapai 50.79\% di atas rerata dan $49.21 \%$ di bawah rerata. Rerata skor kinerja guru sebesar 84.65. Ada 29 orang guru PAUD yang memiliki skor kinerja guru lebih besar atau sama dengan 94.50, dan masih ada 5 orang guru PAUD yang memiliki skor kinerja guru lebih kecil dari 59.49.

\section{Pembahasan}

Interrater reliability persepsi kepala sekolah dan guru PAUD tentang penumbuhan iklim keagamaan di sekolah dapat dievaluasi berdasarkan kriteria Cohen Kappa (Landis \& Kohc, 1977). Ada 6 kategori hasil analisis Cohen Kappa, yaitu kurang dari 0 dimaknai dengan poor aggrement, $\quad 0.0-0.20$ dimaknai slight aggrement, 0.21-0.40 dimaknai fair aggrement, 0.41-0.60 dimaknai dengan moderate aggrement, 0.61-0.80 dimaknai dengan substantial aggrement, dan 0.811.00 dimaknai dengan almost perfect aggrement. Hasil analisis interrater pada Tabel 7 menunjukkan bahwa bobot aggrement sebesar 23.8\%. Hal ini dapat ditafsirkan bahwa kesepatan diantara dua rater masuk dalam kategori fair aggrement atau cukup dipercaya bahwa ada iklim keagamaan yang tumbuh di lingkungan lembaga PAUD.

Tabel 7. Bobot Aggrement Rater 1 \& Rater 2 tenang Iklim Keagamaan di Lembaga PAUD 


\begin{tabular}{|c|c|c|c|c|c|}
\hline \multicolumn{2}{|c|}{ Aggrement Rater 1-2 } & Frequency & Percent & Valid & Cumulative Percent \\
\hline \multicolumn{1}{|c|}{-2.14} & 1 & .8 & .8 & 25.4 \\
\hline-1.43 & 4 & 3.2 & 3.2 & 28.6 \\
\hline-1.43 & 1 & .8 & .8 & 29.4 \\
\hline-.71 & 1 & .8 & .8 & 30.2 \\
\hline-.71 & 1 & .8 & .8 & 31.0 \\
\hline-.71 & 1 & .8 & .8 & 31.7 \\
\hline .71 & 5 & 4.0 & 4.0 & 35.7 \\
\hline .00 & 30 & 23.8 & 23.8 & 59.5 \\
\hline .71 & 5 & 4.0 & 4.0 & 63.5 \\
\hline .71 & 2 & 1.6 & 1.6 & 65.1 \\
\hline .71 & 1 & .8 & .8 & 65.9 \\
\hline 1.43 & 2 & 1.6 & 1.6 & 67.5 \\
\hline 1.43 & 1 & .8 & .8 & 68.3 \\
\hline 1.43 & 1 & .8 & .8 & 69.0 \\
\hline 1.43 & 5 & 4.0 & 4.0 & 73.0 \\
\hline 2.14 & 1 & .8 & .8 & 73.8 \\
\hline
\end{tabular}

Sumber: Data Penelitian Mandiri 2017.

Analisis korelasi antara iklim keagamaan dengan perkembangan nilai agama dan moral anak usia 5-6 tahun diawali dengan memilah data outlier dari yang mengumpul disekitar rerata menggunakan alat bantu $z$-score. Tabulasi data berjumlah 134 set informasi yang berasal dari guru PAUD dan kepala sekolah. Hasil analisis $z$-score ditemukan 8 set data yang memiliki angka $z$-socre lebih kecil dari -2 dan atau lebih besar dari +2 . Jumlah data yang dianalisis sebanyak 126 set data.

Langkah selanjutnya adalah menguji data berdistribusi frekuensi secara normal atau tidak. Berdasarkan skor rasio skewness maupun rasio kurtosis dari masing-masing satuan data yang dianalisis, tidak ada satu pun yang lebih kecil dari -2 dan atau lebih besar dari +2 , sehingga dapat disimpulkan bahwa data berdistribusi normal dan memenuhi syarat untuk melakukan generalisasi dari populasi ke sample.

Langkah terakhir melakukan analisis korelasi Pearson. Hasil analisi korelasi menunjukkan ada hubungan positif antara iklim keagamaan di sekolah dengan perkembangan nilai agama dan moral anak usia 5-6 tahun se-Kota Yogyakarta. Hal ini dibuktikan dengan skor korelasi sebesar 0.772 yang menandakan ada korelasi yang kuat diantara keduanya karena telah melampaui kriteria minimal skor korelasi $\geq 0.5$.

Tabel 8. Korelasi Positif antara Iklim Keagamaan dengan Perkembangan NAM anak usia 5-6 tahun.

\begin{tabular}{|c|c|c|c|}
\hline \multicolumn{4}{|c|}{ Correlations } \\
\hline & & $\begin{array}{c}\text { Iklim } \\
\text { Keagamaan }\end{array}$ & $\begin{array}{l}\text { Perkemb. } \\
\text { NAM }\end{array}$ \\
\hline \multirow[t]{3}{*}{$\begin{array}{c}\text { Iklim } \\
\text { Keagamaan }\end{array}$} & $\begin{array}{c}\text { Pearson } \\
\text { Correlation }\end{array}$ & 1 & $.772^{* *}$ \\
\hline & $\begin{array}{l}\text { Sig. (2- } \\
\text { tailed) }\end{array}$ & & .000. \\
\hline & $\mathrm{N}$ & 126 & 126 \\
\hline \multirow[t]{3}{*}{$\begin{array}{l}\text { Perkemb. } \\
\text { NAM }\end{array}$} & $\begin{array}{c}\text { Pearson } \\
\text { Correlation }\end{array}$ & $.772^{* *}$ & 1 \\
\hline & $\begin{array}{l}\text { Sig. (2- } \\
\text { tailed) }\end{array}$ & .000. & \\
\hline & $\mathrm{N}$ & 126 & 126 \\
\hline
\end{tabular}

Sumber: Data penelitian mandiri 2017

Pengujian hipotesis penelitian dilakukan melalui dua prosedur, yaitu dengan membandingkan t-hitung dengan $\mathrm{t}$ tabel dan berdasarkan skor probabilitas. Cara memperoleh t-hitung menggunakan rumus: $t=\frac{r \sqrt{n-2}}{\sqrt{1-r^{2}}}$. Hasil perhitungan $\mathrm{t}$ hitung sebesar 13.524, sedangkan t-tabel diperoleh dengan cara mencari lokasi $t$ di 0.025 dengan degree of freedom 124 dan ditemukan angka 1.960. Hipotesis yang diuji adalah jika t-hitung $<$ t-tabel, maka null hypothesis diterima, sebaliknya jika thitung > t-tabel, maka null hypothesis ditolak. Bunyi null hypothesis adalah tidak ada hubungan antara iklim keagamaan di sekolah dengan perkembangan NAM anak usia 5-6 tahun.

Berdasarkan perbandingan skor thitung (13.524) dan t-tabel (1.960), maka dapat disimpulkan bahwa t-hitung lebih besar dari t-tabel. Hal ini berarti ada hubungan antara iklim keagamaan di sekolah dengan perkembangan NAM anak usia 5-6 tahun karena null hypothesis ditolak. Hasil pengujian ini didukung oleh skor probabilitas (0.000) yang lebih kecil dari 0.05. Hal ini menandakan korelasi antara kedua variable bersifat signifikan.

\section{UCAPAN TERIMA KASIH}

Terima kasih kepada Pengurus IGTKI Kota Yogyakarta yang telah membantu pengambilan data penelitian. Terima kasih juga kepada dua mahasiswa bimbingan yang sudah ujian skripsi, yaitu Esti Yuliati dan Suci Lukitasari atas bantuan dan kerjasamanya dalam melakukan penelitian ini. 
DAFTAR PUSTAKA

Altares, P.S. (et.al.). (2003). Elementary statistics: A modern approach. Manila: Rex Book Store.

Amir Syamsudin. (2016). Evaluasi ketercapaian standar isi perkembangan nilai-nilai agama dan moral anak usia dini pada semester gassal 2016/2017 KB/TK Pedagogia. Jurnal Pendidikan Anak, Volume 5, Edisi 2, Desember 2016. Hlm 765-777.

Anonim. (t.t.). Data referensi pendidikan. http://referensi.data.kemdikbud.go. id/index21.php?kode $\quad=046000$ \&level $=2$.

Bartkowski, J.P., Xiaohe Xu, Levin, M.L. (2008). Religion and child development: Evidence from the Early Childhood Longitudinal Study. Social Science Research, 37, pp. 18-36.

Fan, C.S. (2006). Religious participation and children's education:A social capital approach. Journal of Economic Behavior \& Organization. Versi elektronik dengan DOI:10.1016/j.jebo.2005. 11.002 .

Gunnestad, A. \& S'lungile Thwala. (2011). Resilience and religion in children and youth in Southern Africa. International Journal of Children's Spirituality. Vol. 16, No. 2, May 2011, 169-185.

Harris, P.L. \& Koenig, M.A. (2006). Trust in Testimony: How Children Learn About Science and Religion. Child Development, May/June 2006, Volume 77, Number 3, Pages 505 524.

Itulua-Abumere, F. (2013). The Significance of Religious Education in Local Primary Schools (Specific Reference to Christianity) dalam IOSR Journal Of Humanities And Social Science (IOSR-JHSS) ISSN: 2279-0837, ISBN: 2279-0845. Volume 6, Issue 6 (Jan. - Feb. 2013), PP 69-94.

Joko Pamungkas, Amir Syamsudin, \& Nur Cholimah. (2016). Kesiapan lembaga paud Sleman untuk penumbuhan budi pekerti dan karakter anak usia dini. Yogyakarta: Sekretariat Daerah Kabupaten Sleman Bekerjasama dengan Universitas Negeri Yogyakarta Tahun 2016. Proses Penerbitan.

Kitching, K., and Shanneik, Y. (2015). Children's beliefs and belonging:A schools and families report from the 'making communion' study. Ireland: University College Cork.

Krejcie, R.V., \& Morgan, D.W. (1970). Determining sample size for research activities. Educational and Psychological Measurement. Vol. 30: 607-610.

Landis, J. R., Koch, G. G. (1977). The measurement of observer agreement for categorical data. Biometrics 33:159-174.

Leunissen, M. (2012). “Aristotle on Natural Character and Its Implications for Moral Development" dalam Journal of the History of Philosophy, vol. 50, no. 4, hlm. 507-530.

Mahoney, A., Pargament, K.I., Tarakeshwar, N., Swank, A.B. (2001). Religion in the home in the 1980s and 1990s: A meta-analytic revies and conceptual analysis of links between religion, marriage, and parenting. Journal of family 
psychology, 2001, Vol.15, No. 4, 559-596.

Rakhma. (2017). Orangtua, kenalkan agama dan Tuhan kepada anak usia dini. Kompas.com. http://lifestyle.kompas.com/read/20 17/01/15/151500920/orangtua.kena lkan.agama.dan.tuhan.kepada.anak. usia.dini.

Scheaffer, R.L., Mendenhall, W., Ott, L. (1990). Elementary survey sampling. Boston: PWS-KENT Publishing Company.

Singgih Santoso. (2014). Statistik parametrik. Jakarta: PT Elex Media Komputindo.

Wessells, Michael, and Strang, A., 'Religion as Resource and Risk: The double-edged sword for children in situations of armed conflict', in Boothby, Neil et. al. (eds.). (2006). A World Turned Upside Down: Social Ecological Approaches to Children in War Zones. Bloomfield, CT: Kumarian Press.

Yamane, T. (1967). Elementary sampling theory. Englewood Cliffs, N.J: Prentice-Hall, Inc. 